\title{
Polymer-Based Approach in Ceramic Materials Processing for Energy Device Applications
}

\author{
Mahendra Rao Somalu ${ }^{1 *}$, Abdullah Abdul Samat ${ }^{1}$, Andanastuti Muchtar ${ }^{1,2}$ and Nafisah Osman ${ }^{3}$ \\ ${ }^{1}$ Fuel Cell Institute, Universiti Kebangsaan Malaysia, Malaysia \\ ${ }^{2}$ Department of Engineering and Built Environment, Centre for Materials Engineering and Smart Manufacturing (MERCU), Universiti Kebangsaan \\ Malaysia, Malaysia \\ ${ }^{3}$ Faculty of Applied Sciences, Universiti Teknologi MARA, Malaysia
}

Submission: June 11, 2018; Published: September 14, 2018

*Corresponding author: Mahendra Rao Somalu, Fuel Cell Institute, Universiti Kebangsaan Malaysia, 43600 UKM Bangi, Selangor, Malaysia, Tel: +6 038911 8522; Fax: +6 038911 8530; Email: mahen@ukm.edu.my

\begin{abstract}
Polymer-based approach such as sol-gel method is a well-known method to produce ceramics materials with excellent properties for a better performance of solid oxide fuel cell. The properties of the materials are generally controlled by chemical agents used in this method. The roles of the chemical agents including chelating agent, polymerization or esterification agent and surfactant are presented and briefly discussed in this mini review paper.
\end{abstract}

Keywords: Sol-gel method; Polymerization agent; Surfactant; Electrolyte; Anode; Cathode; Solid oxide fuel cell; Microstructure

Abbreviations: SOFCs: Solid Oxide Fuel Cells; SSR: Solid-State Reaction; WCMs: Wet Chemical Methods; CA: Citric Acid; EDTA: Ethylene Diamine Tetra-Acetic Acid; EG: Ethylene Glycol; TETA: Triethylenetetramine; PEG: Poly-Ethylene Glycol; PVA: Polyvinyl Alcohol; PVP: Polyvinyl Pyrrolidone; YSZ: Yttria-Stabilized Zirconia; AC: Activated Carbon

\section{Introduction}

High temperature perovskite-type oxide conductive ceramics have attracted great attention worldwide due to the fact that these materials have a great potential to be used as electrolyte and cathode components in solid oxide fuel cells (SOFCs). SOFC is currently deemed as one of the most promising future power generation devices due to its high energy conversion efficiency, less/zero pollutant emission and able to operate on various fuels. Two major concerns that limited the performance of the current developed SOFC systems are low electrolyte conductivity and high electrode polarization resistance [1,2]. Controlling and modifying the microstructural properties of the ceramics components of SOFC is a promising way to tackle the concerns and could be achieved by selecting suitable ceramics processing routes as they greatly affect the microstructure properties of the produced ceramics materials [3]. Traditionally, a Simple SolidState Reaction (SSR) method is used to prepare the perovskitetype oxide ceramics materials [4-7]. However, this method resulted in a poor microstructural property of the produced powders due to high temperature of treatment $\left(>1400{ }^{\circ} \mathrm{C}\right)$ and the produced powders are frequently contaminated $[8,9]$. Hence, Wet Chemical Methods (WCMs) are introduced to overcome the drawbacks of the SSR method. The WCMs are able to produce fine powders with high purity and good homogeneity at lower processing temperature than that of the SSR method $[3,10]$. One the most popular WCMs is a sol-gel method. The preparation of materials through this method is thoroughly discussed in the following section.

\section{Sol-gel Method}

A sol-gel method has been introduced in the 1800 s to produce inorganic ceramics and glass materials [11]. It is a process to form oxide linkages via inorganic polymerization reaction. It starts with a reaction between molecular precursor and solvent to form metal organic complexes. The complexes will undergo polymerization process to yield colloid or sol followed by hydrolysis to form a gel. Then, the gel will turn into ceramics powder after drying and sintering processes [12]. A simple illustration of the sol-gel processes is shown in Figure 1.

There are two basic chemical reactions involve in sol-gel method which preserve the homogeneity of the metal salts (precursor materials) in the solution into gel. The first one is the complexation between metal ions and chelating agent such as Citric Acid (CA) and Ethylenediaminetetra-Acetic Acid (EDTA) which provides a stable metal-chelate in the solution by preserving atomic scale homogeneity. Another one is polymerization of the complexes with polymerizing agent or 
surfactant such as Ethylene Glycol (EG) which forms threedimensional structures that hinder ion mobility and segregation.
A simple illustration of the chemical reactions which involves in this method is shown in Figure 2 [13].
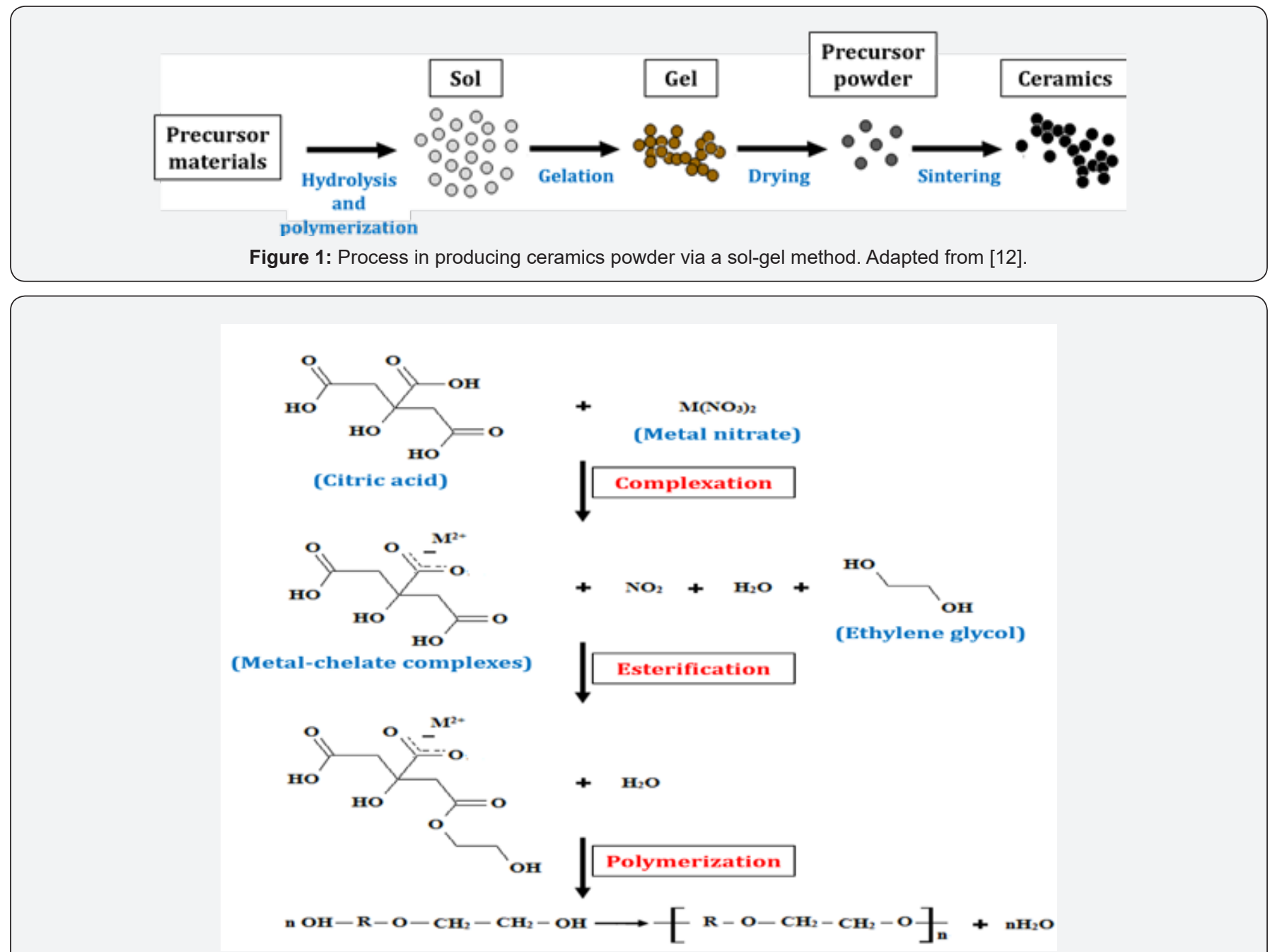

Figure 2: Chemical reactions in a sol-gel method. Adapted from [13].

\section{Roles of Chemical Agents}

Generally, a chelating agent acts to bind all the metal cations of the precursor materials to form a stable metal complexes in a precursor materials solution with homogenous distribution at atomic or molecular level. The addition of chelating agent is able to control the rate of hydrolysis reaction, phase transition, particle size and powder morphology [14]. CA and EDTA are the most conventional chelating agents used to produce various ceramics materials for SOFC application. They can be used separately as a single (CA/EDTA) chelating agent [15-17] or together as a combined (CA-EDTA) chelating agent [18-20]. A combined chelating agent is better than a single chelating agent because it is able to bind almost all metal cations and form more stable complexes than a single chelating agent. Moreover, it is less sensitive to $\mathrm{pH}$ value of the complexes solution and able to reduce the temperature required for single phase powder formation [21,22]. Besides, non-conventional chelating agents such as Triethylenetetramine (TETA), glycolic acid, nitriloacetic acid and tartaric acid have been also used to improve the properties of $\mathrm{BaCe}_{0.54} \mathrm{Zr}_{0.36} \mathrm{Y}_{0.1} \mathrm{O}_{2.95}$ electrolyte material for proton-conducting SOFC application [23].

Ethylene Glycol (EG) is a conventional solvent used in a solgel method. It acts as polymerization agent or esterification agent to produce cathode and electrolyte materials such $\mathrm{La}_{0.6} \mathrm{Sr}_{0.4} \mathrm{CoO}_{3-\delta}$ [20], $\mathrm{BaCe}_{0.54} \mathrm{Zr}_{0.36} \mathrm{Y}_{0.1} \mathrm{O}_{2.95}$ [24], Sm1-xCaxFeO3 [25] and SrCox [13] for SOFC applications. EG aids to form a stable polymer resin of metal-chelate complexes. The formation of polymer resin hinders the formation of particle agglomeration by forming rigid network which controls the movement of metal cations in the complex solution of precursor materials during heat treatment process [26-28]. For better properties of the produced powder, the amount of chelating agent and polymerization agent need to be optimized and controlled.

In a modified sol-gel method, a surface-active agent or simply known as surfactant is used to replace EG as a solvent. Surfactant is an amphiphilic compound consists of hydrophilic polar group and hydrophobic non-polar group. The polar and 
non-polar groups are the head and tail of a surfactant monomer, respectively. Surfactant is classified into three groups based on the charge of the polar group which are ionic (anionic or cationic), non-ionic and dipolar or zwitterionic. The non-polar group is made up of long-chain hydrocarbon or siloxane chain [29]. A simple diagram of a surfactant monomer is shown in Figure 3.

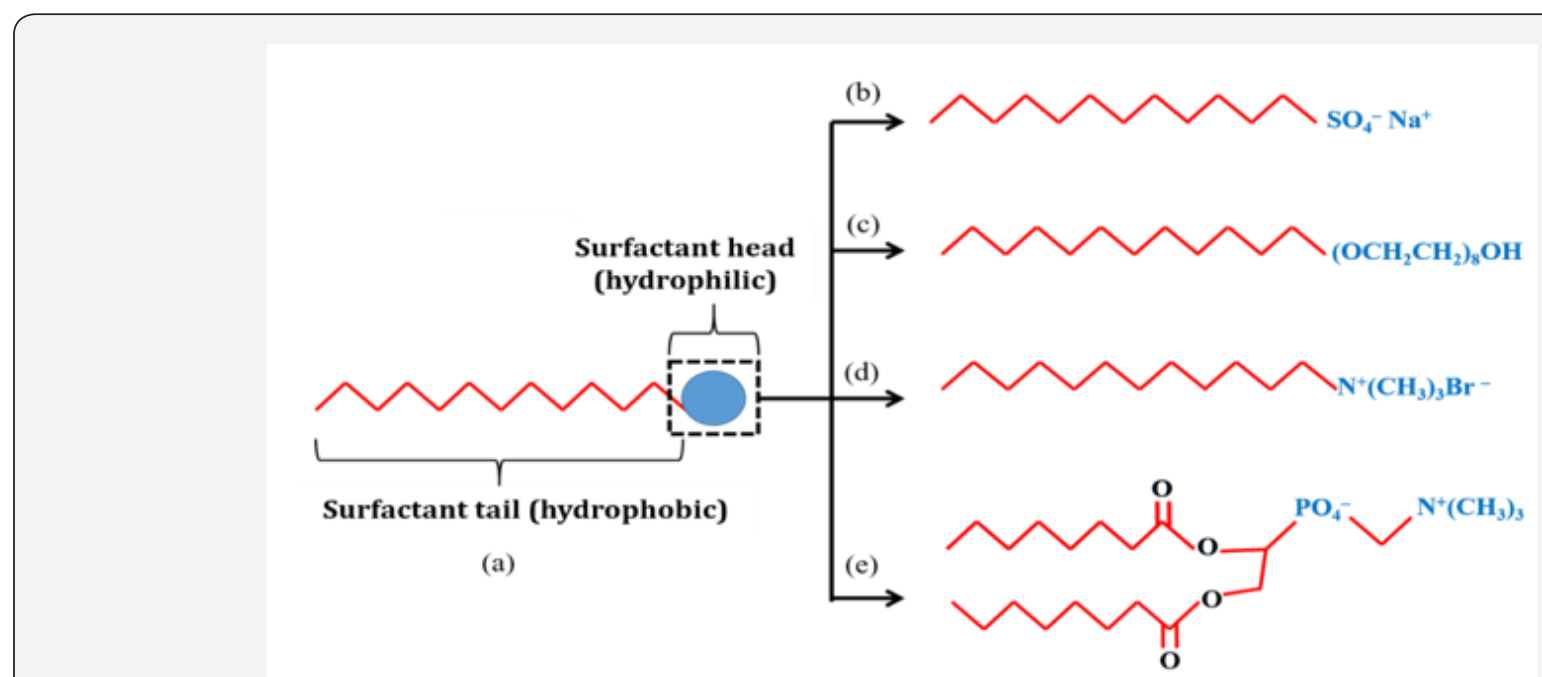

Figure 3: A simple diagram of (a) surfactant monomer, (b) anionic surfactant, (c) non-ionic surfactant, (d) cationic surfactant and (e) zwitterionic surfactant.

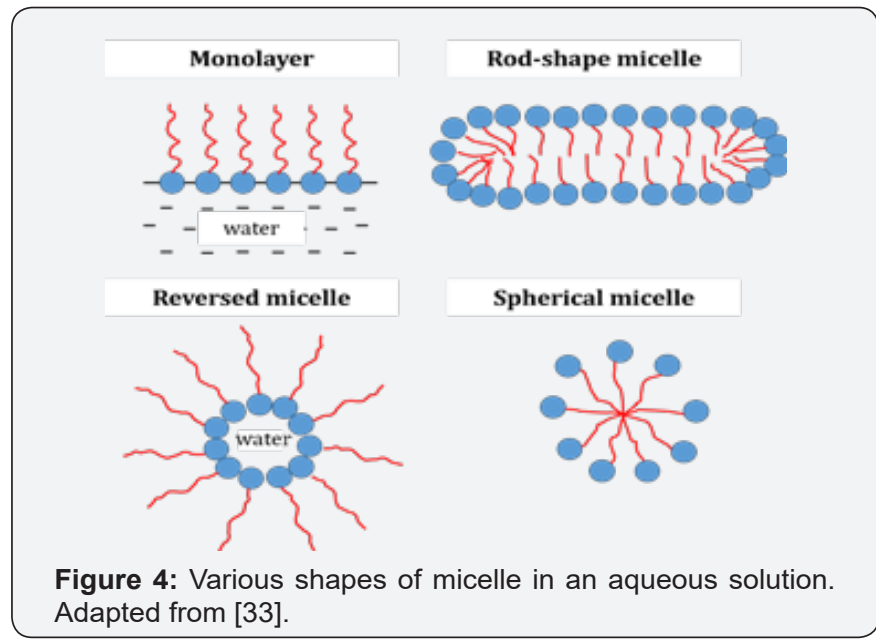

A surfactant can increase miscibility, colloidal stabilization and particle dispersion in a material with various components because of its unique properties of self-assembly. These properties help to reduce the tension of two or more components in a solution system and change the properties of the surface of the solution and increase the compatibility between the particles with different properties in the solution [30,31]. In addition, a surfactant can control the shape and particle size of the produced ceramics materials. It forms a cluster of thermodynamically stable supramolecular known as micelle or microemulsion [32]. Micelle can form in various shapes in an aqueous solution as shown in Figure 4. It is dependent on temperature, surfactant concentration, surfactant composition and $\mathrm{pH}$ [29]. The variation in the micelle shapes is one of the factors that affects the particle shape and size of the produced powder [24].

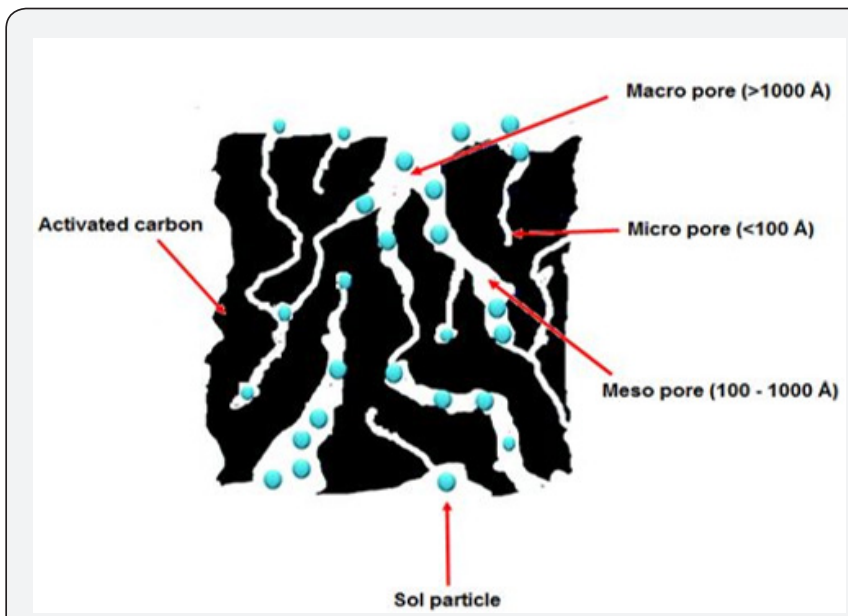

Figure 5: A schematic diagram of an activated carbon. Adapted from [44].

There are many surfactants which have been used to produce ceramic materials for SOFC components via a sol-gel method [33]. Pluronic F127 (tri-block copolymer) and Triton-X-100 were used to synthesis $\mathrm{La}_{0.58} \mathrm{Sr}_{0.4} \mathrm{Fe}_{0.8} \mathrm{Co}_{0.2} \mathrm{O}_{3-\delta}$ [34,35], and Poly-Ethylene Glycol (PEG) was used to synthesize $\mathrm{La}_{0.6} \mathrm{Sr}_{0.4} \mathrm{CoO}_{3-\delta}$ cathode materials. Polyvinyl Alcohol (PVA) and Polyvinyl Pyrrolidone (PVP) were used to synthesize $\mathrm{La}_{0.8} \mathrm{Sr}_{0.2} \mathrm{MnO}_{3-\delta}$ cathode material [36]. All of these surfactants helped to reduce the particle size from micro to nano, increase the surface area and homogeneity of the produced powders. The same results were also reported for the synthesis of electrolyte materials of Yttria-Stabilized Zirconia (YSZ) [37], $\mathrm{Ce}_{0.9} \mathrm{Gd}_{0.1} \mathrm{O}_{1.95}$ [38], $\mathrm{Ce}_{0.8} \mathrm{Sm}_{0.2} \mathrm{O}_{2-\delta}$ [39], and $\mathrm{BaCe}_{0.54} \mathrm{Zr}_{0.36} \mathrm{Y}_{0.1} \mathrm{O}_{2.95}$ [24], using various surfactants. Additionally, surfactant also helps to reduce the temperature required to produce single phase powder and high-density pellet $[38,40]$. 
In addition, Activated Carbon (AC) has been introduced as a dispersing agent in a modified sol-gel method to produce perovskite-type oxide conductive ceramics for SOFC application. The use of $\mathrm{AC}$ as a dispersing agent is quite a new invention in sol-gel method. AC, which is a treated form of carbon with high degree of microporosity, surface area (300-2000m2g-1) and well adsorption ability, is used to replace the conventional solvent or surfactant in the conventional sol-gel method. Like the other chemical agents, AC is also responsible for controlling the nucleation process, phase development and particle growth

Table 1: Properties of ceramic materials produced by sol-gel and other methods for SOFC application.

\begin{tabular}{|c|c|c|c|c|c|}
\hline Ceramic Material & Synthesis Method & Chemical agent & Particle size (nm) & SBET $\left(\mathrm{m}^{2} \mathrm{~g}^{-1}\right)$ & Reference \\
\hline \multirow{5}{*}{$\mathrm{La}_{0.6} \mathrm{Sr}_{0.4} \mathrm{Co}_{0.2} \mathrm{Fe}_{0.8} \mathrm{O}_{3-\delta}$} & \multirow{2}{*}{ Sol-gel } & CA-EDTA and EG & 34 & 12 & \multirow{2}{*}[41]{} \\
\hline & & CA-EDTA and AC & 36 & 11 & \\
\hline & $\begin{array}{l}\text { Microwave-assisted } \\
\text { combustion }\end{array}$ & - & 113 & 12 & {$[45]$} \\
\hline & Citrate-hydrothermal & & 975 & 5 & [46] \\
\hline & SSR & & & $4-13$ & [47] \\
\hline \multirow{5}{*}{$\mathrm{La}_{0.6} \mathrm{Sr}_{0.4} \mathrm{CoO}_{3-\delta}$} & \multirow{5}{*}{ Sol-gel } & $\mathrm{CA}$ & & 14 & {$[48]$} \\
\hline & & CA and EG & $50-200$ & & [49] \\
\hline & & CA-EDTA and AC & $219-221$ & 10 & {$[42]$} \\
\hline & & CA-EDTA and EG & $130-260$ & & {$[20]$} \\
\hline & & CA-ETDA and PEG & 60 & 7 & {$[50]$} \\
\hline \multirow{4}{*}{$\mathrm{BaCe}_{0.54} \mathrm{Zr}_{0.36} \mathrm{Y}_{0.1 \mathrm{O}_{3-\delta}}$} & Sol-gel & CA, EG and Brij97 & $20-80$ & & {$[24]$} \\
\hline & Sol-gel & CA-EDTA and TETA & $342-396$ & & \multirow{3}{*}[51]{} \\
\hline & Supercritical fluid & & $531-712$ & & \\
\hline & $\begin{array}{l}\text { Sol-gel assisted supercritical } \\
\text { fluid }\end{array}$ & & $255-295$ & & \\
\hline \multirow{3}{*}{$\mathrm{Ce}_{0.8} \mathrm{Sm}_{0.2} \mathrm{Ba}_{0.8} \mathrm{Y}_{0.2} \mathrm{O}_{3-\delta}$} & Co-precipitation & & 60 & & \multirow{3}{*}[52]{} \\
\hline & Sol-gel & $\mathrm{CA}$ & 67 & & \\
\hline & Ball milling & & 75 & & \\
\hline \multirow{4}{*}{$\mathrm{Gd}_{0.1} \mathrm{Ce}_{0.9} \mathrm{O}_{1.95}$} & \multirow{3}{*}{ Sol-gel } & EG & & 16 & {$[53]$} \\
\hline & & Tartaric acid & & 13 & \\
\hline & & Glycerol & & 16 & \\
\hline & Co-precipitation & & & 105 & {$[54]$} \\
\hline \multirow{4}{*}{$\mathrm{CeO}_{2}$ doped with $\mathrm{Gd}, \mathrm{Nd}$ and $\mathrm{Sm}$} & Combustion & & $5-8$ & $29-36$ & \multirow{4}{*}[55]{} \\
\hline & Hydrothermal & & $4-8$ & $43-57$ & \\
\hline & SSR & & $90-400$ & $2-3$ & \\
\hline & Co-precipitation & & 3-5 & $88-123$ & \\
\hline
\end{tabular}

The improved properties of the produced ceramics materials by sol-gel method are very important for better electrochemical performance of the SOFC components [44-48]. The properties i.e. particle size and BET specific surface area (SBET) of some common ceramic materials for SOFC application produced by different chemical agents via sol-gel method and other synthesis methods are tabulated in Table 1 . It can be seen that the properties of the produced ceramic materials are different. It is due to the different chemical agents used in the sol-gel method and the different in the method used to produce the ceramic materials [49-52]. The discrepancy in the mentioned properties during the synthesis process. However, it has different reaction mechanism as compared with the other chemical agents. AC traps the metal complexes in precursor solution in its highly porous microstructure through van der Waals attraction, creating well-dispersed particles of the produced ceramic materials after calcination process (Figure 5). Its potential in modifying microstructure of perovskite-type ceramic materials with good electrochemical performance particularly for SOFC application have been reported by Ismail et al. [41] and Abdul S et al. [42,43]. 
continuously improving with time, many other materials can be used as chemical agents. Additional studies of basic understanding on how the chemical agents work and what are the condition they work at the best, including composition, $\mathrm{pH}$, concentration and processing temperatures much be investigated in detail.

\section{Acknowledgement}

The authors would like to acknowledge the Research University grant (DIP-2016-005) provided by Universiti Kebangsaan Malaysia. Abdullah Abdul Samat thankfully acknowledges the Ministry of Higher Education of Malaysia and Universiti Malaysia Perlis for the SLAB/SLAI PhD scholarship.

\section{References}

1. Peng B, Gang Chen, Tao Wang, Jun Zhou, Jiaojiao Guo, et al. (2012) Hydride reduced $\mathrm{LaSrCoO}_{4-\delta}$ as new cathode material for $\mathrm{Ba}$ $\left(\mathrm{Zr}_{0.1} \mathrm{Ce}_{0.7} \mathrm{Y}_{0.2}\right) \mathrm{O}_{3}$ based intermediate temperature solid oxide fuel cells. J Power Sources 201: 174-178.

2. Wang MS, Wang JX, Chang RH, Xue YJ, Miao H, et al. (2015) A novel composite cathode $\mathrm{La}_{0.6} \mathrm{Sr}_{0.4} \mathrm{CoO}_{3-\delta}-\mathrm{BaZr}_{0.1} \mathrm{Ce}_{0.7} \mathrm{Y}_{0.1} \mathrm{Yb}_{0.1} \mathrm{O}_{3-\delta}$ for intermediate temperature solid oxide fuel cells. Ceramics International 41(3): 5017-5025.

3. Shao Z, Zhou W, Zhu Z (2012) Advanced synthesis of materials for intermediate-temperature solid oxide fuel cells. Progress in Materials Science 57(4): 804-874.

4. Subardi A, Chen CC, Fu YP (2017) Oxygen transportation, electrical conductivity and electrochemical properties of layered perovskite $\mathrm{SmBa}_{0.5} \mathrm{Sr}_{0.5} \mathrm{Co}_{2} \mathrm{O}_{5+\delta^{\circ}}$. International Journal of Hydrogen Energy 42(8): 5284-5294.

5. Yoo S, Jiyoun K, Song SY, Lee DW, Shin J, et al. (2014) Structural, electrical and electrochemical characteristics of $\mathrm{La}_{0.1} \mathrm{Sr}_{0.9} \mathrm{Co}_{1-\times} \mathrm{Nb}_{\mathrm{x}} \mathrm{O}_{3-\delta}$ as a cathode material for intermediate temperature solid oxide fuel cells. RSC Advances 4: 18710-18717.

6. Petit CTG, Tao S (2013) Structure and conductivity of praseodymium and yttrium co-doped barium cerates. Solid State Sci 17: 115-121.

7. Pornprasertsuk R, Kosasang O, Somroop K, Horprathum M, Limnonthakul P, et al. (2011) Proton conductivity of Y-doped $\mathrm{BaZrO}_{3}$ : Pellets and thin films. Solid State Sciences 13(7): 1429-1437.

8. Osman N, Yaakob MH, Talib IA (2014) Effect of Metal Chloride PreCursor on the Structure of $\mathrm{Yb}$-Doped $\mathrm{Ba}(\mathrm{Ce}, \mathrm{Zr}) \mathrm{O}_{3}$ Ceramics Electrolyte: A Comparative Study with Different Metal Salts. Sains Malays 43(9): 1429-1432.

9. Vahid Mohammadi A, Cheng Z (2015) Fundamentals of Synthesis, Sintering Issues, and Chemical Stability of $\mathrm{BaZr}_{0.1} \mathrm{Ce}_{0.7} \mathrm{Y}_{0.1} \mathrm{Yb}_{0.1} \mathrm{O}_{3-\delta}$ Proton Conducting Electrolyte for SOFCs. Journal of Electrochemical Society 162(8): F803-F811.

10. Naeem Khan M, Savaniu CD, Azad AK, Hing P, Irvine JTS (2017) Wet chemical synthesis and characterisation of $\mathrm{Ba}_{0.5} \mathrm{Sr}_{0.5} \mathrm{Ce}_{0.6} \mathrm{Zr}_{0.2} \mathrm{Gd}_{0.1} \mathrm{Y}_{0.1} \mathrm{O}_{3}$ ${ }_{-\delta}$ proton conductor. Solid State Ionics 303: 52-57.

11. Hench LL, West JK (1990) The sol-gel process. Chem Rev 90(1): 33-72.

12. Portier J, Choy JH, Subramanian MA (2001) Inoganic-organic-hybrids as precursors to functional materials. Int J Inorg Mater 3(7): 581-592.

13. Gaoke Z, Ying L, Xia Y, Yanping W, Shixi O, et al. (2006) Comparison of synthesis methods, crystal structure and characterization of strontium cobaltite powders. Material Chemistry and Physics 99(1): 88-95.

14. Farhadian Azizi K, Bagheri-Mohagheghi MM (2013) Transition from anatase to rutile phase in titanium dioxide $\left(\mathrm{TiO}_{2}\right)$ nanoparticles synthesized by complexing sol-gel process: effect of kind of complexing agent and calcinating temperature. Journal of Sol-Gel Science and Technology 65(3): 329-335.

15. Bai Y, Liu M, Dind D, Blinn K, Qin W, et al. (2012) Electrical and electrocatalytic properties of a $\mathrm{La}_{0.8} \mathrm{Sr}_{0.2} \mathrm{Co}_{0.17} \mathrm{Mn}_{0.83} \mathrm{O}_{3-\delta}$ cathode for intermediate-temperature solid oxide fuel cells. Journal of Power Sources 205: 80-85.

16. Ghouse M, Al-Yousef Y, Al-Musa A, Al-Otaibi MF (2010) Preparation of $\mathrm{La}_{0.6} \mathrm{Sr}_{0.4} \mathrm{Co}_{0.2} \mathrm{Fe}_{0.8} \mathrm{O}_{3}$ nanoceramic cathode powders for solid oxide fuel cell (SOFC) application. Int J Hydrog Energy 35(17): 9411-9419.

17. Zhuang S, Liu Y, Zeng S, Lv J, Chen X, et al. (2016) A modified sol-gel method for low-temperature synthesis of homogeneous nanoporous $\mathrm{La}_{1-\mathrm{x}} \mathrm{Sr}_{\mathrm{x}} \mathrm{MnO}_{3}$ with large specific surface area. J Sol-Gel Sci Technol 77: 109-118.

18. Jiang X, Wang J, Jia G, Qie Z, Shi Y, et al. (2017) Characterization of $\mathrm{PrBa}_{0.92} \mathrm{CoCuO}_{6-\delta}$ as a potential cathode material of intermediatetemperature solid oxide fuel cell. Int J Hydrog Energy 42(9): 62816289.

19. Abdullah NA, Hasan S, Osman N (2013) Role of CA-EDTA on the Synthesizing Process of Cerate-Zirconate Ceramics Electrolyte. J Chem 2013: 1-7.

20. Abdul Samat A, Somalu MR, Muchtar A, Hassan OH, Osman N (2016) LSC cathode prepared by polymeric complexation method for protonconducting SOFC application. J Sol-Gel Sci Technol 78(2): 382-393.

21. Shao J, Tao Y, Wang J, Xu C, Wang WG (2009) Investigation of precursors in the preparation of nanostructured $\mathrm{La}_{0.6} \mathrm{Sr}_{0.4} \mathrm{Co}_{02} \mathrm{Fe}_{0.8} \mathrm{O}_{3-8}$ via a modified combined complexing method. J Alloys Compd 484(12): $263-267$.

22. Zhou W, Shao Z, Jin W (2006) Synthesis of nanocrystalline conducting composite oxides based on a non-ion selective combined complexing process for functional applications. J Alloys Compd 426(1-2): 368-374.

23. Abdullah NA, Osman N, Hasan S, Hassan OH (2012) Chelating Agents Role on Thermal Characteristics and Phase Formation of Modified Cerate-Zirconate via Sol-gel Synthesis Route. Int J Electrochem Sci 7: 9401-9409.

24. Mazlan NA, Osman N, Md Jani AM, Yaakob MH (2016) Role of ionic and nonionic surfactant on the phase formation and morphology of $\mathrm{Ba}(\mathrm{Ce}, \mathrm{Zr}) \mathrm{O}_{3}$ solid solution. J Sol-Gel Sci Technol 78(1): 50-59.

25. Huízar-Félix AM, Hernández T, de la Parra S, Ibarra J, Kharisov B (2012) Sol-gel based Pechini method synthesis and characterization of $\mathrm{Sm}_{1-\mathrm{x}} \mathrm{Ca}_{\mathrm{x}} \mathrm{FeO}_{3}$ perovskite $0.1 \leq \mathrm{x} \leq 0.5$. Powder Technol 229: 290-293.

26. Gaudon M, Laberty-Robert C, Ansart F, Stevens P, Rousset A (2002) Preparation and characterization of $\mathrm{La}_{1-\mathrm{x}} \mathrm{Sr}_{\mathrm{x}} \mathrm{MnO}_{3+\delta}(0 \leqslant \mathrm{x} \leqslant 0.6)$ powder by sol-gel processing. Solid State Sci 4(1): 125-133.

27. Majedi A, Abbasi A, Davar F (2016) Green synthesis of zirconia nanoparticles using the modified Pechini method and characterization of its optical and electrical properties. J Sol-Gel Sci Technol 77(3): 542552.

28. Razpotnik T, Maček J (2007) Synthesis of nickel oxide/zirconia powders via a modified Pechini method. J Eur Ceram Soc 27(2-3): 1405-1410.

29. Rangel-Yagui CO, Pessoa-Jr A, Costa Tavares L (2005) Micellar solubilization of drugs. J Pharm Sci 8(2): 147-165.

30. Heinz H, Pramanik C, Heinz O, Ding Y, Mishra RK, et al. (2017) Nanoparticle decoration with surfactants: Molecular interactions, assembly, and applications. Surf Sci Rep 72(1): 1-58.

31.John VT, Simmons B, McPherson GL, Bose A (2002) Recent developments in materials synthesis in surfactant systems. Curr Opin Colloid Interface Sci 7(5-6): 288-295. 
32. Huang G, Xu S, Li L, Wang X (2014) Effect of surfactants on dispersion property and morphology of nano-sized nickel powders. Trans Nonferrous Met Soc China 24(11): 3739-3746.

33. Dixit SG, Mahadeshwar AR, Haram SK (1998) Some aspects of the role of surfactants in the formation of nanoparticles. Colloids Surf Physicochem Eng Asp 133(1-2): 69-75.

34. Serra JM, Buchkremer HP (2007) On the nanostructuring and catalytic promotion of intermediate temperature solid oxide fuel cell (IT-SOFC) cathodes. J Power Sources 172(2): 768-774.

35. Burye TE, Nicholas JD (2016) Precursor solution additives improve desiccated $\mathrm{La}_{0.6} \mathrm{Sr}_{0.4} \mathrm{Co}_{0.8} \mathrm{Fe}_{0.2} \mathrm{O}_{3-\mathrm{x}}$ infiltrated solid oxide fuel cell cathode performance. J Power Sources 301: 287-298.

36. Zhu X, Ding D, Li Y, Lü Z, Su W, et al. (2013) Development of $\mathrm{La}_{0.6} \mathrm{Sr}_{0.4} \mathrm{Co}_{0.2} \mathrm{Fe}_{0.8} \mathrm{O}_{3-\delta}$ cathode with an improved stability via $\mathrm{La}_{0.8} \mathrm{Sr}_{0.2} \mathrm{MnO}_{3}$-film impregnation. Int J Hydrog Energy 38(13): 53755382 .

37. Laberty-Robert C, Ansart F, Castillo S, Richard G (2002) Synthesis of YSZ powders by the sol-gel method: surfactant effects on the morphology. Solid State Sci 4(8): 1053-1059.

38. Tao Y, Shao J, Wang J, Wang WG (2009) Morphology control of $\mathrm{Ce}_{0.9} \mathrm{Gd}_{0.1} \mathrm{O}_{1.95}$ anopowder synthesized by sol-gel method using PVP as a surfactant. J Alloys Compd 484(1-2): 729-733.

39. Chima NB, Patrick NG (2014) Effect of nonionic, anionic, and cationic surfactants on the sol gel synthesis of IrO-Ce ${ }_{0.8} \mathrm{Sm}_{0.2} \mathrm{O}_{2-\delta}$ nanocomposite for solid oxide fuel cell application. J Fuel Cell Sci Technol 11(4): 9.

40. Lou Z, Dai N, Wang Z, Die Y, Yan Y, et al. (2013) Preparation and electrochemical characterization of Ruddlesden-Popper oxide $\mathrm{La}_{4} \mathrm{Ni}_{3} \mathrm{O}_{10}$ cathode for IT-SOFCs by sol-gel method. J Solid State Electrochem 17(10): 2703-2709.

41. Ismail I, Osman N, Md Jani AM (2016) Tailoring the microstructure of $\mathrm{La}_{0.6} \mathrm{Sr}_{0.4} \mathrm{Co}_{0.2} \mathrm{Fe}_{0.8} \mathrm{O}_{3-\alpha}$ cathode material: the role of dispersing agent. J Sol-Gel Sci Technol 80(2): 259-266.

42. Abdul Samat A, Jais AA, Somalu MR, Osman N, Muchtar A, Lim KL (2018) Electrical and electrochemical characteristics of $\mathrm{La}_{06} \mathrm{Sr}_{04} \mathrm{CoO}_{3-\delta}$ cathode materials synthesized by a modified citrate-EDTA sol-ge method assisted with activated carbon for proton-conducting solid oxide fuel cell application. J Sol-Gel Sci Technol 86(3): 617-630.

43. Abdul Samat A, Somalu MR, Muchtar A, Osman N (2016) Preparation of Lanthanum Strontium Cobalt Oxide Powder by a Modified Sol-Ge Method. Malays J Anal Sci 20(6): 1458-1466.

This work is licensed under Creative Commons Attribution 4.0 License DOI: 10.19080/AJOP.2018.01.555571
44. Thamilselvan A, Nesaraj AS, Noel M (2016) Review on carbon-based electrode materials for application in capacitive deionization process. Int J Environ Sci Technol 13(12): 2961-2976.

45. Muhammed Ali SA, Anwar M, Somalu MR, Muchtar A (2017) Enhancement of the interfacial polarization resistance of $\mathrm{La}_{0.6} \mathrm{Sr}_{0.4} \mathrm{Co}_{0.2} \mathrm{Fe}_{0.8} \mathrm{O}_{3-\delta}$ cathode by microwave-assisted combustion method. Ceram Int 43(5): 4647-4654.

46. Garcia LMP, Macedo DA, Souza GL, Motta FV, Paskocimas CA, Nascimento RM (2013) Citrate-hydrothermal synthesis, structure and electrochemical performance of $\mathrm{La}_{0.6} \mathrm{Sr}_{0.4} \mathrm{Co}_{0.2} \mathrm{Fe}_{0.8} \mathrm{O}_{3-\delta}$ cathodes for ITSOFCs. Ceram Int 39(7): 8385-8392.

47. Letilly M, Joubert O, Le Gal La Salle A (2012) Characterisation and optimisation of the cathode/electrolyte couple for SOFC LSCF/BIT07. J Power Sources 212: 161-168.

48. Liu Y, Liu Y, Ma J, Lai J (2010) $\mathrm{La}_{1-\mathrm{X}} \mathrm{Sr}_{\mathrm{x}} \mathrm{CoO}_{3}(\mathrm{x}=0.1-0.5)$ as the cathode catalyst for a direct borohydride fuel cell. J Power Sources 195(7): 1854-1858.

49. Wei F, Cao H, Chen $X$ (2016) $\mathrm{La}_{0.6} \mathrm{Sr}_{0.4} \mathrm{CoO}_{3-8}-\mathrm{Ce}_{0.8} \mathrm{Gd}_{0.2} \mathrm{O}_{2-8}$ nanocomposites prepared by a sol-gel process for intermediate temperature solid oxide fuel cell cathode applications. J Mater Sci 51(4): 2160-2167.

50. Tao Y, Shao J, Wang J, Wang WG (2008) Synthesis and properties of $\mathrm{La}_{06} \mathrm{Sr}_{0.4} \mathrm{CoO}_{3-\delta}$ nano powder. J Power Sources 185(2): 609-614.

51. Ibarahim NA, Osman N, Mohd Ishak MA (2015) Particle Size Distribution of Cerate-Zirconate Powder Prepared via Three Different Methods. Adv Mater Res 1108: 67-72.

52. Tariq S, Marium A, Raza R, Ahmad A, Khan MA, et al. (2018) Comparative study of $\mathrm{Ce}_{080} \mathrm{Sm}_{020} \mathrm{Ba}_{080} \mathrm{Y}_{020} \mathrm{O}_{3-\delta}$ (YB-SDC) electrolyte by various chemical synthesis routes. Results Phys 8: 780-784.

53.Zarkov A, Stanulis A, Salkus T, Kezionis A, Jasulaitiene J, et al. (2016) Synthesis of nanocrystalline gadolinium doped ceria via sol-gel combustion and sol-gel synthesis routes. Ceram Int 42(3): 3972-3988.

54. Biesuz M, Dell'Agli G, Spiridigliozzi L, Ferone C, Sglavo VM (2016) Conventional and field-assisted sintering of nanosized Gd-doped ceria synthesized by co-precipitation. Ceram Int 42(10): 11766-11771.

55. Kim G, Naesung Lee Ki-Beum Kim Byung-Kook Kim, Hyejung Chang, et al. (2013) Various synthesis methods of aliovalent-doped ceria and their electrical properties for intermediate temperature solid oxide electrolytes. Int J Hydrog Energy 38(3): 1571-1587.

\section{Your next submission with Juniper Publishers will reach you the below assets}

- Quality Editorial service

- Swift Peer Review

- Reprints availability

- E-prints Service

- Manuscript Podcast for convenient understanding

- Global attainment for your research

- Manuscript accessibility in different formats

( Pdf, E-pub, Full Text, Audio)

- Unceasing customer service

Track the below URL for one-step submission

https://juniperpublishers.com/online-submission.php 